\title{
Planning, property and profit: the use of financial viability modelling in urban property development
}

\author{
EDWARD MITCHELL
}

\author{
School of Law, University of Essex
}

\begin{abstract}
By drawing upon McAuslan's analysis of the ideologies underpinning land use planning law, this paper examines financial viability modelling and legal processes in the context of local authority decision-making related to property development on large urban sites. A local authority can make a site ready for development by using 'compulsory purchase' powers to acquire land, by transferring that land to a property developer and by granting that developer planning permission to commence construction. Analysis of case law, academic criticism of viability modelling practices and a recent property development project highlight issues arising when local authority planning departments use viability appraisals to legitimise decisions purportedly taken in the public interest. An in-depth examination of viability modelling within local authority estates departments then opens a new site for critical inquiry of local authority land acquisition practices. The paper's conclusions reflect upon how financial viability modelling shapes decision-making, despite questions surrounding both modelling techniques and the outputs that viability appraisals produce.
\end{abstract}

Key words: compulsory purchase; local authorities; property development; planning; viability.

\section{Introduction}

L ocal authority planning departments in England formulate and apply policies for property development in their areas. Local authority estates departments, on the other hand, often use both the local authority's landholdings and the local authority's power to 'compulsorily purchase' privately owned land to stimulate property development activity. By granting planning permission to property developers and by transferring both their own and compulsorily purchased land to those developers, these local authority departments facilitate the 'assembly' of land for property development purposes. ${ }^{1}$

A type of financial viability modelling device, called a development viability appraisal (DVA), is integral to each aspect of land assembly. Local authority planning departments use DVAs in negotiations with property developers on such things as the amount of 'affordable housing'2 a specific project should provide. DVAs are also a component of a common form of conditional property development contract, known as a development

1 Discussed in Antonia Layard, 'Shopping in the public realm: a law of place' (2010) 37(3) Journal of Law and Society 412.

2 Lower-cost housing sold or rented below market value: see Ministry of Housing, Communities and Local Government (MHCLG), National Planning Policy Framework (MHCLG 2019) Annex 2. 
agreement (DA), made between local authority estates departments and property developers to consolidate disparate urban landholdings into plots capable of accommodating large-scale property development projects.

This paper identifies problems that emerge when local authority planning and estates departments use DVAs as decision-making tools during land assembly. To analyse these problems, the paper considers McAuslan's well-known examination of the 'ideologies' running through land use planning law. ${ }^{3}$ For McAuslan, this law includes legislation and judicial decisions related to development control and compulsory purchase activity ${ }^{4}$ and the 'paraphernalia of plans, hearings, appeals, notices, orders, circulars, agreements, etc' that these activities generate. ${ }^{5}$ McAuslan's account pinpoints three competing ideologies that complicate decision-making within the context of land use planning: first, that the law exists to protect and serve private property rights; second, that the role of the law is to promote the public interest; and, third, that the law should promote public participation in land use planning. ${ }^{6}$ This paper moves McAuslan's ideas into a new area by focusing on how councillors, local authority officers, third-party consultants and property developers working on land assembly projects formulate and pursue a shared vision of the public interest. The paper argues that this manifests most clearly in an assumption that there is a public interest, first, in enhancing the monetary profit accruing from particular projects and, second, in carefully controlling public participation in the decision-making processes at play in this context.

To illustrate how conflicting notions of the public interest create tensions in land assembly practice, this paper studies a recent project in Winchester (the Winchester Development), a small city in the south of England. The local authority participating in the Winchester Development (Winchester Council) did so by attempting to address what Harding has called 'the ownership logjam'. 7 This arises if ownership of landholdings on an earmarked development site is spread across landowners who refuse to participate in the redevelopment of that land. To address this, Winchester Council granted a preselected property developer planning permission to construct an agreed set of buildings and used a DA with that developer to acquire those landholdings and thus assemble a development site in an area deemed to be blighted by a downtrodden property market and a lack of 'investability'. The ostensible goal was the construction of new buildings on a predefined site to leverage the provision of urban housing and other public goods and to bring associated 'trickle-down' benefits to the area through the creation of

3 Patrick McAuslan, The Ideologies of Planning Law (Pergamon Press 1980).

4 When discussing development control, McAuslan examines how decision-makers determine applications for planning permission (ibid 147). When discussing compulsory purchase, McAuslan addresses compensation payable to landowners when public bodies expropriate their property rights (ibid 103). This paper does not consider the compensation regime but, instead, discusses the law regulating the use of compulsory purchase powers.

5 Ibid 268.

6 For more recent discussions of these ideologies, see Julie Adshead, 'Revisiting the ideologies of planning law: private property, public interest and public participation in the legal framework of England and Wales' (2014) 6(1/2) International Journal of Law in the Built Environment 174 and Emma Lees and Edward Shepherd, 'Incoherence and incompatibility in planning law' (2015) 7(2) International Journal of Law in the Built Environment 111.

7 Anne Harding, 'The rise of urban growth coalitions, UK-style' (1991) 9(3) Environment and Planning C: Government and Policy 295, 314. See also Anna Minton, Ground Control: Fear and Happiness in the TwentyFirst-century City (1st edn, Penguin Books 2009) and Peter Wyatt, Property Valuation (2nd edn, John Wiley \& Sons 2013) 427. 
jobs and an enhancement in land values. ${ }^{8}$ This paper examines, however, the tensions to which Winchester Council had to respond when promised planning gains and perceptions of development viability exerted competing pressures. The paper also shows how a DA functions as a type of legal-economic hybrid that regulates the transfer of compulsorily purchased land from private to public ownership and then from public ownership into a new form of private ownership on terms conditioned by the outputs of DVAs. The paper then analyses how, as Henderson has put it, local authorities involved in this type of property development activity treat land assembly and private profit 'as a public interest objective' that trumps other policy goals. ${ }^{9}$

The tensions examined in this paper were highlighted in court proceedings related to the Winchester Development ${ }^{10}$ but also emerged in various documents that Winchester Council produced for consideration at internal meetings and that its officers presented to a public inquiry convened to consider its use of compulsory purchase powers. These documents provide important empirical data because they record what local authority officers and councillors read and said about DAs, DVAs and land assembly. The paper also inspects the findings of the Information Commissioner (IC) in response to public complaints about the availability of information related to the financial underpinnings of the Winchester Development. Alongside this examination of local authority decisionmaking and financial viability modelling in the context of the Winchester Development, the paper probes other recent judicial decisions related to planning, DVAs and public participation in land assembly processes. Taken together, this range of sources reveals the contradictions that emerge when the public interest dimension of planning becomes synonymous with the pursuit of private commercial imperatives.

The paper addresses these tensions in five sections. First, the paper introduces the Winchester Development and elaborates on McAuslan's analysis of the ideologies at play in planning law. The second section then discusses critical studies of financial viabilitymodelling practices, judicial decisions involving DVAs and aspects of the Winchester Development to analyse the tensions that emerge when planning departments and property developers use DVAs to reduce or avoid any obligation to provide public goods, such as affordable housing, which would otherwise be imposed as a condition of the grant of planning permission. The paper's third section then considers various access to information requests to highlight conflicts related to public participation in the use of DVAs. The paper then shifts focus to examine the land acquisition aspect of land assembly. It does so by analysing data drawn from the Winchester Development and by considering the High Court case of $\mathrm{R}$ (on the application of Wylde) $v$ Waverley Borough Council. ${ }^{11}$ This section unpicks the interrelationship between DAs and DVAs to analyse land valuation and public procurement controversies arising from viability-led changes to local authority-property developer DAs. The paper concludes by reflecting upon how financial viability shapes local authority decision-making, despite questions surrounding the robustness and objectivity of modelling techniques, the underlying assumptions and the outputs that DVAs produce.

8 Winchester CC, The Winchester CC (Silver Hill) Compulsory Purchase Order 2011. Statement of Case (22 March 2012) paragraph 8.4. This process has also been examined in legal and urban regeneration studies (see Layard (n 1), Minton (n 7) and, for an American perspective, Debbie Becher, Private Property and Public Power: Eminent Domain in Philadelphia (Oxford University Press 2014).

9 Steven R Henderson, 'City centre retail development in England: land assembly and business experiences of area change processes' (2011) 42 Geoforum 592, 599.

$10 \mathrm{R}$ (on the application of Gottlieb) v Winchester City Council [2015] EWHC 231 (Admin) (hereafter Gottlieb).

11 [2017] EWHC 466 (Admin) (hereafter Wylde). 


\section{Silver Hill, Winchester}

The choice of the Winchester Development as the focal point of this paper followed the aforementioned Gottlieb judicial review. ${ }^{12}$ The decision to focus primarily on a single project was also, however, a product of the complex interplay between planning and land acquisition decision-making and the explanatory detail required to highlight the specific problems arising from the use of DVAs in land assembly practice. Moreover, examining a single project enables, paraphrasing McAuslan, a close examination of the occasions during land assembly when ideological conflicts arise. ${ }^{13}$ The Winchester Development provides particularly rich insights because of the frequency with which Winchester Council and the Winchester Developer used DVAs in an effort to legitimise controversial planning and land acquisition decisions. In addition, studying the Winchester Development reveals limitations to the scope of access to information laws as a means for public scrutiny of the DVAs that are crucial to land assembly processes.

The urban site that Winchester Council's Estates Department ${ }^{14}$ identified in the late1990 s as suitable for property development (the Winchester Site) consisted of five Winchester Council-owned landholdings, Winchester's privately owned bus station and other landholdings owned by various third parties. ${ }^{15}$ The Winchester Development began when Thornfield Properties (Winchester) Ltd agreed, with the owner of the bus station, to redevelop that land. ${ }^{16}$ The Developer then attempted, unsuccessfully, to reach land acquisition agreements with other landowners with interests on the Winchester Site. ${ }^{17}$ The combination of the Developer's agreement in relation to the bus station, the fragmented nature of landownership on the Site and Winchester Council's desire for development illustrates why a local authority estates department and a property developer might agree a conditional property development contract containing a land assembly mechanism.

Winchester Council's Estates Department and the Winchester Developer signed a DA on 22 December 2004 (the WDA), in which they agreed that the Development would include various commercial buildings, a new bus station and at least 287 homes, of which

12 Gottlieb (n 10).

13 McAuslan (n 3) 269.

14 Winchester Council operates an Estates Department (Winchester CC, Constitution of the City Council - Part 7 - Management Structure (adopted 26 June 2019)), which has been tasked with 'maximising' the revenue that the Council's land generates (as stated in part 7 of the previous iteration of the Constitution (adopted 7 February 2017)). Christophers explains the long history of central and local government initiatives, often involving privatisation schemes, designed to maximise revenues produced from local authority-owned land: see Brett Christophers, The New Enclosure: The Appropriation of Public Land in Neoliberal Britain (Verso 2018). A current example is the One Public Estate project: Local Government Association, One Public Estate: Building a Movement through Partnership (Local Government Association 2018).

15 Winchester CC, CAB1030. Broadway Friarsgate - Development Agreement. Report of Chief Estates Officer (February 2005) appendix 1. When this research began, documents related to the Winchester Development cited in this paper were available on the Council's website. Winchester Council has since redesigned its website and some documents are no longer available. The author has copies of documents cited in this paper available for review on request.

16 Thornfield Properties (Winchester) Ltd was a property development company established specifically for the Winchester Development. In 2010, its parent company (Thornfield Properties plc) entered administration and Henderson Real Estate acquired the development company and changed its name to Silverhill Winchester No 1 Ltd: see Winchester CC, CAB2085. Silver Hill Regeneration Project - Latest Developments. Report of the Chief Executive (November 2010). The shorthand 'the Winchester Developer' is used here for simplicity.

17 Matthew Bodley, Proof of Evidence (presented to the Public Inquiry held to consider the Winchester CC (Silver Hill) Compulsory Purchase Order 2011) (May 2012). 
35 per cent were to be affordable. ${ }^{18}$ To enable construction to commence, the Developer agreed to apply for planning permission ${ }^{19}$ and to continue its attempt to acquire all required landholdings not in the ownership of Winchester Council. If the Developer failed to acquire those landholdings, Winchester Council's Estates Officers agreed that they would attempt to complete the acquisition process using the Council's compulsory purchase powers and by leasing the entire Site to the Developer. ${ }^{20}$ This paper consequently examines the negotiations that took place between the Winchester Developer and Winchester Council's Planning and Estates Departments until the Gottlieb judgment determined that the Council's decision to approve variations to the WDA was unlawful. The High Court's decision led to the collapse of the Development in March 2016, ${ }^{21}$ so the decision to examine the Winchester Development means studying a project that failed. Nevertheless, the longevity of the project meant that the Council and the Developer engaged with various legal processes. This variety provides multiple original insights into how legal mechanisms regulate this type of land assembly activity.

Much of the law in this area, McAuslan has argued, is dominated by two ideologies. On the one hand, McAuslan suggests, the courts often interpret and apply land use planning law in a way that prioritises private property rights over other interests. ${ }^{22} \mathrm{On}$ the other hand, McAuslan highlights the tendency amongst the politicians and local authority officers who formulate and apply land use planning law to construct and interpret that law primarily in accordance with a broadly defined public interest ideology. ${ }^{23}$ Sections 226(1)(a) and (1A) of the Town and Country Planning Act 1990 (TCPA 1990) exemplify the latter tendency. These provisions permit a local authority to make a compulsory purchase order (CPO) if it believes that expropriating third-party land would 'facilitate ... development, redevelopment or improvement' and would be likely to contribute social, economic or environmental benefits to the wider area. In the context of land assembly, the public interest ideology underpinning these provisions often manifests in the use of public powers to realign existing private property rights to enable land uses deemed to be more socially and economically productive. ${ }^{24}$ This is a use of legal mechanisms to resolve a conflict between how public administrators perceive the public interest and the rights of a private property owner to use her land in ways that challenge the pursuit of presumed public interest goals. While McAuslan suggests that there is a complex interplay between these dominant ideologies in this and in other aspects of land use planning, he also argues that the content, interpretation and application of law often diminishes the role of public participation. This is because public participation is seen as a threat to the predominance of these ideologies. ${ }^{25}$ According to this outlook, enhanced public

18 Clause 5.3 of the WDA called these the 'required elements'. The WDA originally required 364 new homes, but a Deed of Variation reduced this to 287 (Winchester CC, CAB2603. Silver Hill Regeneration. Report of the Silver Hill Officers Project Team (July 2014) paragraph 2.4). The WDA is available, as of 16 October 2019, for download in four parts, with variations in 2009 and 2010, from

<https://www.whatdotheyknow.com/request/a_copy_of_the_contract_between_h>.

19 WDA, schedule 2, paragraph 3.3.

20 WDA, clauses 10.1 and 11.2.

21 Winchester CC, Withdrawal of Silver Hill Appeal by Developer (Press release 7 April 2016).

22 McAuslan (n 3) 3.

23 Ibid 4.

24 Brett Christophers, 'Geographical knowledges and neoliberal tensions: compulsory land purchase in the context of contemporary urban redevelopment' (2010) 42(4) Environment and Planning A: Economy and Space 856, 864.

25 Adshead's more recent analysis of public participation in land use planning law provides examples of situations in which McAuslan's critique still applies: Adshead (n 6) 187. 
participation in the substantive aspects of land use decision-making might improve public satisfaction with and produce greater clarity in processes, decisions and outcomes. ${ }^{26}$

Land assembly practices highlight conflicts between public interest goals, protection for private property rights and public participation mechanisms. This paper focuses particularly on how councillors, local authority officers, third-party consultants and property developers use DVAs to determine how far land assembly projects should comply with policies related to the provision of affordable housing or the price property developers should pay for local authority land. The paper also probes the tensions that emerge when members of the public seek to intervene in land assembly practices. These tensions flow from a perception, on the part of some local authorities, that these DVAs are themselves a type of private property and that disclosure of them will be detrimental to both a property developer's right to maximise its profits and a local authority's efforts to promote property development in accordance with its perception of the public interest. Public participation thus creates, from the perspective of these local authorities, an interference with both private property rights and the public interest ideology underpinning land assembly decision-making. By following McAuslan's lead, this paper examines what contractual agreements, judicial and ministerial decisions, central and local government policies, documents submitted to and emanating from CPO inquiries and reports related to local authority land transfers show about the legal mechanisms that administrators and developers use to pursue their vision of the public interest and to restrict public participation in viability-related decisions.

\section{Financial viability modelling, planning and affordable housing}

The National Planning Policy Framework (NPPF) encourages planning departments to assess the amount of affordable housing required in their area 27 and to set targets for affordable housing provision on individual development sites. ${ }^{28}$ To do so, planning departments commonly use actual and hypothetical projects on land identified as suitable for residential development to assess the financial viability of specific targets. ${ }^{29}$ Thirdparty consultants then convert a proposed affordable housing target into a monetary figure, which can be added to likely land acquisition, site preparation, construction and other costs in DVAs relevant to the various schemes. ${ }^{30}$ A proposed target is 'viable' if projected revenues sufficiently outweigh projected costs. A planning department can then incorporate that target into its development plan as a policy priority to be considered in relation to applications for planning permission. Planning departments can then seek to ensure affordable housing provision through 'planning obligations', in a 'section 106

26 McAuslan (n 3) 269.

27 MHCLG (n 2) paragraph 60.

28 Ibid paragraph 62.

29 Brett Christophers, 'Wild dragons in the city: urban political economy, affordable housing development and the performative world-making of economic models' (2014) 38(1) International Journal of Urban and Regional Research 79. In addition to the texts referred to in this and in subsequent footnotes, this paper draws upon Wyatt (n 7) 403-453 for its understanding of viability modelling practices.

30 Patrick McAllister, Emma Street and Peter Wyatt, 'Governing calculative practices: an investigation of development viability modelling in the English planning system’ (2016) 53(11) Urban Studies 2363, 2366. 
agreement', ${ }^{31}$ in which a developer promises to provide affordable housing in return for the grant of planning permission. ${ }^{32}$

Recent research suggests that policy-making processes afford property developers and landowners control over the formulation of development plan targets because consultants producing DVAs for local authority planning departments seek 'buy-in' from those groups. ${ }^{33}$ Recent research also, however, identifies problems arising from 'input uncertainty' when officers or consultants assess hypothetical property development schemes based on estimated land values and development costs. ${ }^{34}$ This work criticises the incapacity of planning officers to challenge the conclusions that their consultants reach and the paucity of community involvement in testing viability findings and concludes that DVAs are often insufficiently robust to have become so deeply embedded in the processes that planning departments use to formulate policies. ${ }^{35}$ Moreover, most DVAs prescribe a pre-determined value for private profit. 'Profit', however, is not simply a product of revenue exceeding expenditure. Rather, profit is itself reconfigured as a cost that can be added in a DVA to other costs. These total costs can be weighed against projected revenue to determine if a development is viable. Most DVAs conceptualise profit as a proportion of either projected total costs or estimated development value and stipulate that a developer should be entitled to a profit of 15-20 per cent of either total costs or estimated development value. ${ }^{36}$ This entitlement is a given, ${ }^{37}$ so profit features in these DVAs as a non-negotiable prerequisite to construction commencing. ${ }^{38}$

The use of DVAs in local authority planning practice means that profitability often takes precedence over housing need. But demonstrating that area-wide development plans inscribe a financial logic onto the spaces in which people live addresses only one problematic aspect of the use of viability modelling. As Christophers explains, an effect of the preoccupation with viability at a policy level is to 'explicitly embed viability considerations within another, connected domain: that of on-the-ground negotiations between local authorities and developers'. ${ }^{39}$ This happens because most development

31 So-called because of the operation of section 106, TCPA 1990.

32 See, for example, London Borough of Tower Hamlets, Core Strategy (2010), policy SP13, and Winchester CC, Core Strategy (2013), chapter 10. See also the recommendations in the NPPF (MHCLG (n 2) paragraph 34 ) and the government's accompanying guidance on viability modelling and planning (MHCLG, Viability (last updated 1 September 2019)) <https://www.gov.uk/guidance/viability> paragraph 001.

33 McAllister et al (n 30) 2374, citing Anthony J Jakeman, Rebecca A Letcher and John P Norman, 'Ten iterative steps in development and evaluation of environmental models' (2006) 21(5) Environmental Modelling and Software 602.

34 Peter Byrne, Patrick McAllister and Peter Wyatt, 'Precisely wrong or roughly right? An evaluation of development viability appraisal modelling' (2011) 16(3) Journal of Financial Management of Property and Construction 249; Neil Crosby, Patrick McAllister and Peter Wyatt, 'Fit for planning? An evaluation of the application of development viability appraisal methods in the UK planning system' (2013) 40(1) Environment and Planning B: Planning and Design 3.

35 Christophers (n 29) 94.

36 Charlotte Coleman, Neil Crosby, Patrick McAllister and Peter Wyatt, 'Development appraisal in practice: some evidence from the planning system' (2013) 30(2) Journal of Property Research 144, 158-161.

37 Antonia Layard, 'Planning by numbers: affordable housing and viability in England' in Mike Raco and Federico Savini (eds), Planning and Knowledge: How New Forms of Technocracy Are Shaping Contemporary Cities (Policy Press 2019) 213-224, 218.

38 Christophers (n 29) 87.

39 Ibid 87. See also Neil Crosby and Peter Wyatt, 'Financial viability appraisals for site-specific planning decisions in England' (2016) 34(8) Environment and Planning C: Government and Policy 1716 and Patrick McAllister, Peter Wyatt and Charlotte Coleman, 'Fit for policy? Some evidence on the application of development viability models in the United Kingdom planning system' (2013) 84(4) Town Planning Review 495. 
plans state that any application for planning permission for residential development on a site of or over a certain size will be rejected unless the applicant promises that a certain amount of the units to be constructed will be 'affordable'. These policies make affordable housing provision a public interest objective, but most development plans also envisage three possibilities if an applicant can show that provision of the stipulated quantity of affordable housing on-site would render development proposals 'unviable'. First, a local authority can approve an application if the applicant promises to construct the same amount of affordable housing off-site. Secondly, a local authority can approve an application if the applicant promises to pay money in lieu of either on-site or off-site construction. Finally, many local authorities accept that development plan targets might 'need to be varied' further if applicants provide 'detailed and robust financial statements' to justify that outcome. ${ }^{40}$

This creates an incentive for developers to argue that affordable housing targets should not apply to their projects. A property developer seeking planning permission for a large residential development project will usually be required to submit a DVA as part of its application. This can produce what Layard calls 'the duel of the spreadsheets' if a local authority concludes that established targets should apply to a project, but the developer applying for planning permission reaches a different conclusion. ${ }^{41}$ In those circumstances, close scrutiny of the inputs to DVAs is essential because, as analysis of these practices has shown, 'subjective'42 and 'uncertain' 43 estimated land values, site preparation and construction costs and developer revenues are fundamental to showing if specific levels of affordable housing provision would prevent a developer attaining a 'competitive' profit.

While much of this action takes place in behind-the scenes negotiations between planning officers and property developers, planning law is a 'funnel' at which controversies converge. ${ }^{44}$ In Kensington and Chelsea RLBC v Secretary of State for Communities and Local Government, ${ }^{45}$ for example, a property developer (Vannes) applied to a local authority (RBKC) for planning permission for residential property development. RBKC's development plan policies had expired so the case considered the then extant version of the Mayor of London's London Plan. The London Plan provides statutory guidance for London Borough planning departments and stated that each borough should 'encourage rather than restrain residential development', ${ }^{46}$ but that any site with capacity for 10 or more homes would be expected to achieve 50 per cent affordable housing provision. ${ }^{47}$ Vannes and RBKC agreed that the site could accommodate 10 or more homes, but Vannes' application envisaged the construction of nine 'high-end' homes and no affordable housing. To justify deviation from the London Plan, Vannes produced a DVA showing that any affordable housing would render the scheme unviable. RBKC's consultant, however, produced an alternative DVA showing that a development

40 See London Borough of Tower Hamlets, Core Strategy (2010) paragraph 4.4 and Winchester CC, Core Strategy (2013) paragraph 7.22.

41 Layard (n 37) 217. See also Christophers (n 29) 91.

42 Layard (n 37) 221; McAllister et al (n 30) 2376 (in relation to DVAs used for policy formation).

43 Crosby et al (n 34) 9; Crosby and Wyatt (n 39) 1728.

44 Mariana Valverde, Everyday Law on the Street: City Governance in an Age of Diversity (University of Chicago Press 2012) 12.

45 [2010] EWCA Civ 1466 (also known as Vannes KFT $v$ Kensington and Chelsea RLBC). Discussed in Christophers (n 29) 93-94.

46 Kensington and Chelsea (n 45) [11].

47 Ibid [6]. 
incorporating affordable housing would generate a significant profit. ${ }^{48}$ Based on the consultant's DVA, RBKC's planning officers recommended that the Planning Committee should reject Vannes' application, which the Committee did. On appeal, however, a planning inspector overturned RBKC's decision and granted planning permission. The inspector acknowledged that Vannes' DVA contained unreliable data but felt that RBKC's consultant had used similarly unreliable data to assess the site's capacity to achieve viability while accommodating affordable housing. ${ }^{49}$ In the Court of Appeal, Aikens LJ concluded that the inspector was justified in disregarding the conflicting viability data, in attaching more weight to the policy requirement that boroughs should encourage residential development and in granting planning permission for a project that incorporated no affordable housing. ${ }^{50}$

In a more recent dispute over incompatible DVAs, Parkhurst Road Ltd v Secretary of State for Communities and Local Government, ${ }^{51}$ Holgate J upheld a planning inspector's decision not to grant planning permission for a residential development that did not comply with the London Borough of Islington's affordable housing policy. Islington's policy states that every new residential development should provide the 'maximum reasonable amount' of affordable housing. ${ }^{52}$ For the purpose of the disputed application, Islington produced a DVA showing that the developer could construct 34 per cent of the homes as affordable housing. ${ }^{53}$ The developer, however, produced a DVA suggesting that this would render development unviable. ${ }^{54}$ The differences in these DVAs came from conflicting valuations of the development site in its use prior to construction and, consequently, conflicting conclusions as to whether the developer would draw an 'adequate' profit. Holgate $J$ found flaws with both DVAs but concluded that the developer had failed to justify its assertion that 10 per cent affordable housing was the maximum reasonably attainable. ${ }^{55}$

The Parkhurst Road decision, like the decision in Kensington and Chelsea, flowed from a judge grappling with a disagreement between an applicant and a local authority about the use of a DVA, based on questionable inputs, as a tool to determine affordable housing provision. In a postscript to his judgment in Parkhurst Road, Holgate $\mathrm{J}$ noted the 'proliferation of litigation' from viability-related disputes and implored the government and professional bodies to address this. ${ }^{56}$ This 'proliferation', however, represents only one problematic aspect of the use of viability modelling in this context. During the Winchester Development, by contrast, the Developer and Winchester Council agreed that no affordable housing needed to be provided. There was no 'duel of the spreadsheets' here, although a brief history of the Development reveals that problems nonetheless arose from the use of DVAs.

In 2007, the Winchester Developer had applied for permission to construct various residential and commercial buildings. ${ }^{57}$ While the Council's planning policies indicated

48 Ibid [14].

49 Ibid [17]-[25].

50 Ibid [49]-[53].

51 [2018] EWHC 991 (Admin).

52 London Borough of Islington, Core Strategy (2011) paragraph 3.3.30.

53 Parkhurst Road (n 51) [18].

54 Ibid [18].

55 Ibid [131]-[132].

56 Ibid [142]-[147]. See, in relation to this, Royal Institution of Chartered Surveyors (RICS), Financial Viability in Planning: Conduct and Reporting (1st edn, RICS 2019).

57 GVA Grimley LLP, Planning Statement Addendum on bebalf of Thornfield Properties (Winchester) Ltd (January 2007) paragraph 2. 
that any buildings to be constructed on the Site should be no more than 14-15 metres high, ${ }^{58}$ the Developer had argued that these requirements would prevent it from achieving a competitive financial return ${ }^{59}$ and proposed a maximum building height of over 20 metres. ${ }^{60}$ The Developer did, however, offer a policy-compliant affordable housing provision ${ }^{61}$ and a policy-compliant 'public open space' payment. ${ }^{62}$ The Council agreed to grant planning permission as soon as the Developer signed a section 106 agreement in these terms. ${ }^{63}$ The Developer did not do so, however, and, in August 2008, informed Winchester Council that the 2008 economic downturn had diminished the financial viability of the Development. The Developer thus amended its application for planning permission, preserving the proposed building heights but seeking an increase in the overall permitted residential component and a reduction in the proportion of affordable housing. ${ }^{64}$ The Developer also sought the removal of the open space payment. ${ }^{65}$ The Council's planning officers reviewed the Developer's viability assumptions and agreed that the Development could support neither policy-compliant levels of affordable housing nor a public open space payment. ${ }^{66}$ Those officers recommended that the Council should grant planning permission because the overall importance of the project to the area trumped the need for smaller buildings, on-site affordable housing provision or an open space payment. ${ }^{67}$ The Council granted planning permission in February 2009 after the Developer signed a section 106 agreement promising that, if it did not provide the required affordable housing on-site, it would pay the Council an amount equivalent to the cost of on-site provision. ${ }^{68}$

Winchester Council's grant of planning permission might simply indicate a one-off desire to promote development activity following the 2008 economic downturn. However, the Council then agreed subsequent reductions to the public gains on offer. In October 2014, the Developer applied for permission to increase the proposed retail floorspace, reduce the overall residential component and avoid any affordable housing provision and any contribution in lieu of on-site provision. ${ }^{69}$ A policy-compliant financial contribution in lieu would have required a $\AA^{7}$ million payment when construction commenced, ${ }^{70}$ which the Developer stated would prevent 'an acceptable competitive development return'. ${ }^{71}$ Instead, the Developer proposed to pay $\AA_{1}$ million on

58 Winchester CC, PDC673. Report of Director of Development (March 2007) paragraph 10.9.

59 Winchester CC, CAB938. Report of Chief Estates Officer (September/October 2004) paragraph 3.4.2; Winchester CC, CAB1179. Report of Chief Estates Officer (December 2005) paragraph 3.6.

60 Winchester CC, PDC673 (n 58) paragraph 10.9.

61 The Developer proposed to provide 40 per cent of the homes as affordable housing: see also Winchester CC, PDC673 (n 58) paragraph 13.1.

62 In the form of a $f 360,806$ payment. GVA Grimley LLP, Planning Statement on behalf of Thornfield Properties (Winchester) Ltd (May 2007) paragraph 6.17; Winchester CC, PDC673 (n 58) paragraph 22.1; Winchester CC, PDC768. Report of Head of Planning Control (October 2008) paragraph 5.25.

63 Winchester CC, Minutes of the Meeting of the Planning Committee (27 March 2007) Resolution 1.

64 Winchester CC, PDC768 (n 62) paragraph 1.8.

65 Ibid paragraph 1.8 .

66 Ibid paragraph 7.3.

67 Ibid paragraph 7.5.

68 Winchester CC, PDC1012 Item 01, Report to Planning Development Control Committee (December 2014) paragraphs 2.1, 3.4 and 20.1. Christophers notes other examples of developers seeking to renegotiate development proposals incorporating affordable housing provision (n 29) 92.

69 Winchester CC, PDC1012 Item 01 (n 68) paragraph 10.1.

70 Ibid paragraph 20.13.

71 DP9 Ltd, Affordable Housing Statement for Silverbill Winchester No 1 Ltd (October 2014) paragraphs 5.14-16. 
commencement of construction and $£ 1$ million if it accrued a 15 per cent profit on cost. $^{72}$ In response, the Council's planning officers commissioned a review of the DVA that the Developer used to justify these claims. That review questioned some of the inputs to the Developer's DVA ${ }^{73}$ but confirmed that the proposals would produce a return below 'an acceptable range'. ${ }^{74}$ Drawing upon their consultant's assessment, Winchester Council's Planning Department recommended the grant of planning permission for a development incorporating no affordable housing and the aforementioned $£ 1$ million payments, ${ }^{75}$ which the Council's Planning Committee duly confirmed. ${ }^{76}$

The Winchester Development is significant, therefore, because it shows how a Developer might begin planning negotiations with a relatively generous section 106 offer before presenting revised DVAs to reduce the overall public benefits. An administrative preoccupation with facilitating property development and a perception that the public interest is served by using market mechanisms to determine when property development takes place makes this possible. Moreover, critical analyses of financial viability modelling techniques and the outcomes in the Kensington and Chelsea and Parkhurst Road cases show that unreliable inputs can produce disputed outputs and that DVAs are not always suitable tools for legitimising decisions purportedly taken in the public interest.

\section{Financial viability modelling and access to information}

The preceding section of this paper examined the tensions that can arise when decisionmakers seek to balance policies designed to promote profit-generating property development and those directed towards the provision of planning gains such as affordable housing. This section now addresses public participation in that decisionmaking by examining the publication of viability data that the Winchester Developer used to justify its 2014 planning application and by explaining the access to information law relevant to planning proceedings. Examining this provides an opportunity to consider if current access to information provisions counterbalance the close relationship between notions of the public interest and the pursuit of a private profit.

The Local Government Act 1972 (LGA 1972) entitles members of the public to access copies of reports produced for local authority council, committee and subcommittee meetings ${ }^{77}$ and provides a public right of access to background papers used in preparing those reports. ${ }^{78} \mathrm{~A}$ local authority can, however, withhold disclosure of those documents if an officer deems that they are exempt from publication. ${ }^{79}$ Material can be exempt if it relates to any financial or business affairs, ${ }^{80}$ and an officer can show that the public interest favours non-disclosure. ${ }^{81}$ Recently, however, local interest groups have

72 Ibid paragraphs 5.19-22.

73 Deloitte LLP, Silver Hill, Winchester. Viability Assessment (December 2014) paragraph 4.2.

74 Ibid paragraph 3.6.

75 Winchester CC, PDC1012 Item 01 (n 68) paragraph 20.20.

76 Winchester CC, Minutes of the Meeting of the Planning Committee (11 December 2014) Items 1-3.

77 Section $100 \mathrm{~B}(1)$.

78 Section $100 \mathrm{D}(1)$

79 See sections $100 \mathrm{~B}(2)$ and $100 \mathrm{D}(4)$.

80 LGA 1972, schedule 12A, paragraph 3.

81 Ibid schedule 12A, paragraph 10. 
sought to challenge both the ideologies underpinning and flaws inherent to viability modelling techniques but have found that local authorities often refuse to disclose DVAs received from developers. ${ }^{82}$

Following receipt of the Winchester Developer's 2014 planning application, Winchester Council had in its possession an affordable housing statement in which the Developer summarised both the modelling techniques used to assess the economic viability of its proposals and the outputs of its DVAs. ${ }^{83}$ The Developer did not, however, provide Winchester Council with copies of either its DVAs or detailed information about the underlying inputs. ${ }^{84}$ Instead, the Developer provided this material in a 'data room'. 85 Having reviewed the available information, the Council's consultants then confirmed that they believed that the development proposition was not viable. ${ }^{86}$ The Council published the consultant's report and the Council's Planning Committee granted planning permission, having received and considered this report, the Developer's affordable housing statement and a planning officer's report addressing the viability questions. ${ }^{87}$

The information that Winchester Council received raises questions about the material that a planning committee should consider and that a local authority should publish for public scrutiny. These questions have been addressed in recent High Court proceedings. $R$ (on the application of Perry) $v$ London Borough of Hackney ${ }^{88}$ and Turner $v$ Secretary of State for Communities and Local Government ${ }^{89}$ involved projects in which planning departments granted permission for residential developments incorporating affordable housing levels below those required in planning policies. Perry considered an allegation that Hackney's Planning Committee had failed to scrutinise the DVA used to justify the proposals. A planning officer had reviewed the DVA and instructed a third-party consultant to examine the data it contained. This consultant advised that the data in the DVA was robust and the officer communicated this to the Planning Committee in a report assessing the merits of the developer's application. The officer did not provide the Committee with a copy of either the DVA or the consultant's report, however, and the claimant, a local resident, argued that this meant that the Committee did not have access to all the information needed to reach an informed decision as to the application's merits. Turner involved a similar set of facts, albeit that the claimant alleged that a planning inspector appointed to determine a planning application could not reach a valid decision without having seen the DVA a developer used to deviate from the London Borough of Lambeth's affordable housing policy. ${ }^{90}$

The allegations in Perry and Turner mattered to the respective claimants because, as Collins J put it in Turner, materials disclosed to a decision-maker should also be disclosed to an objector. ${ }^{91}$ However, both Collins $\mathrm{J}$ and, in Perry, Patterson J concluded that the

82 See, for example, Jerry Flynn, 'Complete control: developers, financial viability and regeneration at the Elephant and Castle’ (2016) 20(2) City 278.

83 DP9 Ltd (n 71) paragraphs 5.4-5.17.

84 Deloitte LLP (n 73) paragraph 3.1.

85 Ibid paragraph 3.1.

86 Ibid paragraph 4.2.

87 Winchester Council, PDC1012 (n 68).

88 [2014] EWHC 3499 (Admin).

89 [2015] EWHC 375 (Admin).

90 Ibid [16].

91 Ibid [15]. 
respective decision-makers had received sufficient information because officers provided reports summarising the content of both the DVAs and the third-party reviews. ${ }^{92}$ In Perry, Patterson J deemed that there was no basis on which to require disclosure of the DVAs or the accompanying reviews and went on to say, citing an earlier decision of Ouseley $\mathrm{J}$ in $\mathrm{R}$ (on the application of Bedford) $v$ London Borough of Islington, ${ }^{93}$ that obliging planning departments to disclose DVAs might 'hinder' negotiations between a local authority and a developer, prevent development proposals coming forward and obstruct the delivery of public goods such as affordable housing. ${ }^{94}$ The cases also reveal a judicial unwillingness to require planning departments to disclose a developer's viability assumptions if there is a possibility that doing so might undermine a developer's economic interests. Moreover, these cases establish that a local authority planning department will have adequately scrutinised a developer's DVA if it appoints a third-party consultant to report on that DVA and if a planning officer then communicates the contents of that report to the person tasked with determining the planning application. ${ }^{95}$

The Perry and Turner decisions indicate that Winchester Council had probably complied with its obligations in the LGA 1972 when it provided for consideration copies of the Developer's affordable housing statement and its own consultant's report. This situation does little, however, to address questions about a lack of either openness in the use of DVAs or mechanisms for informed public scrutiny of the underlying assumptions. ${ }^{96}$ The Environmental Information Regulations 2004 (EIR 2004), which require a local authority to disseminate certain types of 'environmental information' in its possession ${ }^{97}$ or to make that information available on request, ${ }^{98}$ provide a potential means for enhanced openness. ${ }^{99}$

92 Ibid [25]; Perry (n 88) [64]-[65]. In Turner, Collins J also dismissed the applicant's contention that the inspector's conduct during the original planning proceedings created a perception of bias [67]. The applicant received permission to appeal on this ground, although the Court of Appeal affirmed Collins J's decision: see Turner v Secretary of State for Communities and Local Government [2015] EWCA Civ 582. The Court of Appeal's judgment does not examine the specific viability issues discussed above.

93 [2002] EWHC 2044 (Admin).

94 Perry (n 88) [91]. Patterson J also refused to order disclosure of unredacted copies of the specific DVA to the applicant prior to the judicial review proceedings: see $\mathrm{R}$ (on the application of Perry) $v$ London Borough of Hackney [2014] EWHC 1721 (Admin). The applicant subsequently sought permission to appeal Patterson J's conclusion that the local authority had not unlawfully withheld the viability information from committee members. However, the Court of Appeal refused this application: $\mathrm{R}$ (on the application of Perry) $v$ London Borough of Hackney [2015] EWCA Civ 557.

95 See also Jorren Knibbe, 'Viability assessments, dead rubber appeals, and EU law' (2017) 5 Journal of Planning Law 473. The author first encountered these cases in a seminar paper: Jorren Knibbe and Jay Jagasia, 'Viability assessments and challenges to planning decisions' (April 2015)

<http://www.guildhallchambers.co.uk/uploadedFiles/Viability_Assessments_and $\% 20$ Challenges_to_ Planning_Decisions.pdf $>$; and a presentation on the topic by Andrew Byass, 'Environmental information (and viability assessments)' (January 2017) < https://www.landmarkchambers.co.uk/wpcontent/uploads/2018/07/Environmental-Information-and-Viability-Assessments-ABB.pdf>.

96 Knibbe, 'Viability assessments, dead rubber appeals, and EU law' (n 95) 475.

97 Regulation 4(1).

98 Regulation 5(1).

99 The EIR 2004 employ a broad definition of environmental information that encompasses data in policies, plans, agreements and reports on activities likely to affect the natural environment (regulation 2(1)). Consequently, viability data will often fall within the ambit of the Regulations. See Rebecca Warren, 'A review of the trend towards greater transparency and public access to information in the planning arena with a particular focus on viability appraisals' (2016) 13 Supp (Ch-Ch-Changes...) Journal of Planning Law OP40; and Philip Coppel QC, 'The use and disclosure of confidential information in planning applications' (2016) 3 Journal of Planning Law 204, 218. 
However, the duty to disclose is limited by statutory exemptions and a perception that the public interest might sometimes favour non-disclosure. ${ }^{100}$

The Winchester Development illustrates how administrators might balance public interest arguments for transparency against public interest arguments for protection of purportedly confidential data because, after Winchester Council granted planning permission, a member of the public requested disclosure of the Developer's DVA. ${ }^{101}$ The Council did not hold copies of the DVA, but it did acknowledge that it had some background information related to it, which it refused to disclose. ${ }^{102}$ This information set out the estimated costs of the project, estimated sales and rental values of the buildings to be constructed and the estimated overall profitability. ${ }^{103}$ The applicant consequently complained to the IC alleging that the Council had unlawfully withheld this information. The Council argued that this information was commercially sensitive because disclosure would undermine the Developer's bargaining position in negotiations with residential buyers, ${ }^{104}$ commercial tenants, ${ }^{105}$ building contractors ${ }^{106}$ and other local authorities with which it might seek to engage in property development projects. ${ }^{107}$ While the IC acknowledged that some of the more detailed information related to construction and land acquisition costs was so sensitive that the public interest favoured non-disclosure, ${ }^{108}$ the IC also concluded that there was a strong public interest in the disclosure of the bulk of the information in Winchester Council's possession, particularly in light of the use of the information to justify both the non-provision of affordable housing ${ }^{109}$ and a development that was larger in scale than local planning policy recommended. ${ }^{110}$

This outcome is consistent with recent First-tier Tribunal decisions on the application of the EIR 2004. ${ }^{111}$ In three of those cases, members of the public requested that local authority planning departments disclosed DVAs that developers had used to justify deviations from affordable housing policies. In Southwark, Greenwich and Clyne, the local authorities involved argued that regulation 12(5)(e), which protects the confidentiality of commercial information related to a legitimate economic interest, entitled them to disclose only redacted copies of the developers' DVAs. ${ }^{112}$ In Clyne, the most recent of these decisions, the London Borough of Lambeth argued that the release of a DVA would place the developer at an economic disadvantage when negotiating with both housing associations for the sale of the proposed affordable housing stock and building contractors whom the developer would pay to construct the development. ${ }^{113}$ The tribunal rejected Lambeth's arguments and ordered disclosure of the full DVA, with the

100 Regulation 12(1), EIR 2004.

101 See the Information Commissioners Office's Decision Notice FER0572663 (17 September 2015).

102 Ibid paragraph 7.

103 Ibid paragraph 21.

104 Ibid paragraph 34.

105 Ibid paragraph 35.

106 Ibid paragraph 51.

107 Ibid paragraph 59.

108 Ibid paragraphs 48-49.

109 Ibid paragraph 64.

110 Ibid paragraph 66.

111 London Borough of Southwark v The Information Commissioner EA/2013/0162 (Southwark); Royal Borough of Greenwich v The Information Commissioner EA/2014/0122 (Greenwich) and Clyne v The Information Commissioner EA/2016/0012 (Clyne).

112 Clyne (n 111) paragraph 20(q); Southwark (n 111) paragraphs 35 and 51-52; Greenwich (n 111) paragraphs 15 and 19-21.

113 Clyne (n 111) paragraph 20(q). 
exception of data related to a 'rent-free' period that the developer proposed to offer to certain end-users. ${ }^{114}$ The tribunal did so because it concluded that the data in a DVA provides only a temporary snapshot of likely costs and revenues and disclosure of data that quickly becomes out of date would cause no significant commercial disadvantage. ${ }^{115}$

The tribunals considering the Southwark and Greenwich applications reached similar decisions to that in Clyne, noting the strong public interest in disclosure when DVAs form the basis of contentious planning decisions. ${ }^{116}$ However, these rulings simply reinforce a type of procedural public participation because they led, long after the substantive planning decisions had been taken, only to disclosure of some of the information that had formed the basis for the decisions. ${ }^{117}$ Moreover, there was a notable difference between those rulings and the Winchester Development that highlights further limits to access to information provisions as a tool for public participation in the substance of viability discussions. Winchester Council did not have the Developer's DVA in its possession, presumably so that the access to information provisions in the EIR 2004 could not be applied to it. ${ }^{118}$ This type of dynamic, in which the Developer, first, reduced the proposed planning gains and, second, apparently did not allow its local authority partner to hold a copy of its DVA, has the potential to create suspicion about the basis for and use of viability assumptions. While a Winchester Council member did question the integrity of the Developer's DVAs, ${ }^{119}$ there is no evidence that shows that the Developer did provide an unreliable DVA. However, more openness might have enabled Winchester Council to dispel any such suspicion in relation to the Winchester Development, particularly given the use of the DVA to legitimise controversial planning decisions purportedly being taken in the public interest. Instead, the IC described the information that Winchester Council did hold, in relation to the Developer's DVA, as 'not extensive'. ${ }^{120}$ It is doubtful, therefore, that the published material would have enabled intensive scrutiny of either the Council's decision-making or the Developer's viability assumptions even if it had been released before the Council granted planning permission. Timely publication of detailed viability data might address scepticism about choices administrators and developers make, enable members of the public to contribute to the substance of live viability discussions and provide for meaningful public debate about the reliability of viability findings.

The NPPF now recommends that DVAs, both produced at the plan-making stage and in relation to site-specific applications for planning permission, 'should be made publicly available'. ${ }^{121}$ Some local authorities have also produced guidance stating that developers will be expected to disclose DVAs used during the planning application process. ${ }^{122}$ This guidance suggests that those local authorities are adapting their attitudes to transparency when a property development project rests upon financial viability data. However, the multifaceted legal and practical issues arising from the use of DVAs still produce

114 Ibid paragraph 10 .

115 Ibid paragraphs 19 (i) and 45.

116 Southwark (n 111) paragraph 58; Greenwich (n 111) paragraphs 27-28; Clyne (n 111) paragraph 64.

117 As noted in Flynn (n 82) 280.

118 FER0572663 (n 101) paragraph 21.

119 Winchester CC, OS104. Silver Hill Development Proposal. Report of Cllr Kim Gottlieb (July 2014).

120 FER0572663 (n 101) paragraph 21.

121 MHCLG (n 2) paragraph 57. See also MHCLG (n 32) paragraphs 020-021.

122 See, for example, London Borough of Islington, Development Viability: Supplementary Planning Document (2016) and London Borough of Southwark, Development Viability: Supplementary Planning Document (2016). See also Warren (n 99). 
contentious and controversial outcomes and the High Court and First-tier Tribunal decisions discussed here show how the use of DVAs pulls local authority planning departments in different directions when officers and councillors are asked to balance private profit and public policy goals.

\section{Financial viability modelling, local authority landownership and land assembly}

Despite the criticisms of DVAs outlined above, viability data has also permeated decisionmaking in local authority estates departments. This paper has already explained that Winchester Council's Estates Department entered into a property development contract (the WDA) with the Winchester Developer in which the latter promised to apply for planning permission and then to construct a pre-agreed set of buildings on the Winchester Site. The Winchester Development thus provides an exemplar of the volatile relationship between property development contracts, DVAs and local authority land acquisition strategies.

While Winchester Council owned some of the landholdings on the Winchester Site, its estates officers could not use the WDA to compel the Developer to commence construction until two key pre-conditions had been satisfied. First, a 'Site Assembly Condition' stated that the Developer's promise to commence construction could only become 'fully unconditional' either when the Developer and the Council had acquired all the landholdings or when the Council received confirmation of the validity of a CPO made to that end. ${ }^{123}$ A 'Financial Viability Condition' then added further conditionality to the WDA by stating that the Developer's promise to commence construction would only become binding if the Developer was satisfied as to the viability of the development proposition. The development would be 'viable' only if a DVA, conducted after all other pre-conditions had been satisfied, demonstrated that 'the anticipated profit is not less than $10 \%$ of anticipated Development Costs'.124

The WDA was a legal-economic hybrid that made a guaranteed private profit a contractual right and a preoccupation for the Council's estates officers. This led to a series of profit-driven changes to the WDA. These changes began in 2008 when the Developer produced a DVA showing that the WDA made the Development 'unviable'. ${ }^{125}$ In response, the Council changed the building specifications stipulated in the WDA to ensure that the Developer did not breach the contract when it made its revised 2008 planning application. ${ }^{126}$ The Council also agreed to change the leasing mechanism in the WDA so that the Developer would obtain possession of the Site before construction commenced, ${ }^{127}$ reducing the stamp duty land tax payable on the grant of the lease but

123 WDA, schedule 2, paragraph 2.3. A local authority must submit a CPO that it has made to the Secretary of State for Housing, Communities and Local Government (previously the Secretary of State for Communities and Local Government (abbreviated hereafter to SSCLG)), who appoints a planning inspector to adjudicate at a public inquiry if individuals or organisations whose land is to be acquired object to the CPO (Acquisition of Land Act 1981 (ALA 1981) sections 2(2) and 13A(3)). The SSCLG can either confirm or refuse to confirm a CPO (ALA 1981, section 13A(5)). An estates department can exercise confirmed powers within three years of confirmation (Compulsory Purchase Act 1965, section 4; Compulsory Purchase (Vesting Declarations) Act 1981, section 5A).

124 WDA, schedule 2, paragraph 2.9. Gottlieb (n 10) at [13(iii)]. The sequencing of the conditions in the WDA is typical: the author has copies of various DAs containing similar site assembly and viability conditions available for review on request.

125 Winchester CC, CAB1739. Silver Hill Winchester-Compulsory Purchase Order. Report of Head of Estates (November 2008) paragraph 2.4.

126 Ibid paragraph 9.4.

127 Ibid paragraphs 8.1-8.3. 
transferring the Site to the Developer earlier in the development process. ${ }^{128}$ Having then received assurance that the Development was viable, the Council's estates officers made a CPO in 2011 (the Winchester CPO), which was examined at a public inquiry in 2012 (the Inquiry) and which the SSCLG confirmed in 2013. ${ }^{129}$ To demonstrate that construction would begin soon after confirmation of the CPO, the Council had informed the Inquiry that the WDA committed the Developer to construct the then permitted development. ${ }^{130}$ A Council officer also stated that, before the Inquiry, the Developer had shown that 'the scheme is viable'. ${ }^{131}$ This evidence presented the amended WDA and the pre-Inquiry DVA as a mechanism produced in the public interest to guarantee that construction would commence as soon as the SSCLG confirmed the CPO.

Despite the assurances provided at the Winchester Inquiry, the pre-Inquiry DVA did not discharge the financial viability condition in the WDA because it did not post-date discharge of the other pre-conditions. Moreover, the Council had not disclosed the preInquiry DVA, so there was no scrutiny of the Developer's viability assumptions during the Inquiry. After the Inquiry, the Developer then produced the 2014 DVA that it also presented to the Council's Planning Department to support its application to amend the 2009 planning permission. That DVA showed that the Development would only be viable if the Council's Estates Department agreed further changes to the building specifications stipulated in the WDA. ${ }^{132}$ The Council's estates officers agreed to these changes and the Cabinet approved them in August 2014 (the 2014 Variations). ${ }^{133}$ Between 2008 and 2014, the Developer had thus used three DVAs, each showing different outputs and drawing upon its contractual entitlement to a guaranteed profit, to direct the Council's decisionmaking. By embedding a DVA within the legal underpinnings of the Winchester Development, the Developer had also gained significant control over the purposes for which estates officers deployed the Council's compulsory purchase powers.

However, Winchester Council's Cabinet approval for the 2014 Variations led to the Gottlieb judicial review, ${ }^{134}$ in which a Council member claimed that the Council had breached its public procurement law duties by failing to conduct a tendering exercise before approving the Variations. ${ }^{135}$ The claimant also alleged that estates officers had inadequately scrutinised the Developer's DVAs and that the Council had consequently approved a land assembly mechanism that was not in the public interest because it would not enable the Council to lease the Site at a price equivalent to the 'best consideration'

128 The WDA originally stated that the Council would grant the lease after construction commenced (ibid paragraphs 8.1-8.3). See also WDA, clause 11.2.1.

129 DCLG, The Winchester CC (Silver Hill) Compulsory Purchase Order 2011 - Confirmation Letter (20 March 2013).

130 Winchester CC, Statement of Case (n 8) paragraph 12.1(2).

131 Steve Tilbury, Proof of Evidence (presented to the Public Inquiry held to consider the Winchester City Council (Silver Hill) Compulsory Purchase Order 2011) (May 2012) paragraph 5.3.3.

132 Winchester CC, CAB2603 (n 18), paragraphs 2.4 and 4.11.

133 Winchester CC, Minutes of the Special Cabinet Meeting held on 10 July 2014; Winchester CC, Minutes of the Special Cabinet Meeting held on 6 August 2014.

134 Gottlieb (n 10).

$135 \mathrm{R}$ (on the application of Gottlieb) v Winchester City Council, Order by Dove J, CO/4150/2014 (8 October 2014). 
reasonably available. ${ }^{136}$ Following the 2014 Variations, Winchester Council stood to

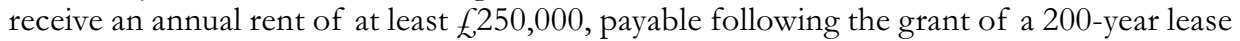
of the Site, and a share of the Developer's profit if that profit exceeded $£ 2$ million. ${ }^{137}$ Around the time that the claimant made his application for judicial review, however, the Developer agreed to increase the minimum annual rent to $f, 305,000 .{ }^{138}$ An applicant will receive permission to seek judicial review if they have a realistic prospect of success ${ }^{139}$ and sufficient interest or standing to bring the claim. ${ }^{140}$ When the High Court considered the claimant's application, Dove J and Lindblom J separately noted that estates officers had received professional advice stating that the Council would obtain the best consideration reasonably available, despite the Developer having subsequently found more money for the Site. The best consideration point consequently had a low prospect of success. ${ }^{141}$ The claimant did, however, obtain permission for judicial review of the alleged procurement law breach. ${ }^{142}$ Lang J then concluded that the 2014 Variations amounted to the formation of a new contract, ${ }^{143}$ that the Council had thus breached public procurement rules and that the Cabinet approval for the Variations was void. ${ }^{144}$

The Wylde decision has since suggested that Lang J erred in her judgment in Gottlieb because she should have concluded that the claimant did not have standing. ${ }^{145}$ The point here is not, however, that a possible procedural shortcoming defeated the Winchester Development. The underlying thread is the use of DVAs. In 2015, an independent review that Winchester Council commissioned indicated that, while the Council had received legal advice stating that the 2014 Variations did not breach procurement rules, earlier legal advice had stated that substantial changes to the WDA would trigger a tendering exercise. ${ }^{146}$ This suggests that the need to produce a positive DVA may have led the Council's officers to advise councillors to take legally risky actions, purportedly in the public interest, to facilitate both the transfer of the Council's landholdings and the commencement of a property development project.

Considered in isolation, the Winchester Development might only reveal how estates officers struggled to reorder landownership on a specific site for presumed public interest purposes while complying with the Council's general public law duties. A brief discussion of the project considered in Wylde, however, shows that other developers have offered one proposition prior to a CPO inquiry before reducing the offer after the SSCLG

136 Ibid. See also: Winchester CC, OS104 (n 119) 6-7; Winchester City Council, CAB2609. Silver Hill Update. Report of Head of Estates (September 2014) paragraph 5.3. When a local authority transfers land it should ensure that it does so at a price equivalent to that which is the best reasonably obtainable (LGA 1972, section 123(2), and TCPA 1990, section 233(3)). A local authority will obtain best consideration if an independent valuation indicates that the price to be received represents the best reasonably obtainable: see $\mathrm{R}$ (on the application of Midlands Co-Operative Society Ltd) v Birmingham City Council [2012] EWHC 620 (Admin) at [124].

137 Winchester CC, CAB2603 (n 18) paragraph 6.7; see also Gottlieb (n 10) [21].

138 Gottlieb (n 10) [38].

139 Sharma v Browne-Antoine [2006] UKPC 57.

140 See section 31(3) of the Senior Courts Act 1981.

141 Order by Dove J (n 135). See also R (on the application of Gottlieb) $v$ Winchester City Council, Order by Lindblom J, CO/4150/2140 (24 November 2014).

142 Gottlieb (n 10) [151]-[152].

143 Ibid [70]

144 Ibid [142].

145 Wylde (n 11) [42]. The Winchester Developer received permission to appeal against Lang J's decision: see $R$ (on the application of Gottlieb) $v$ Winchester City Council [2015] EWCA Civ 1369. The Developer later abandoned that appeal when the deadline for exercise of the Winchester CPO expired (see n 21).

146 Claer Lloyd-Jones, A Perfect Storm - Report on Silver Hill (January 2016) paragraph 5.21 and appendix 4. 
confirms a CPO. In 2003, Waverley Borough Council (Waverley) and Crest Nicholson Developments Ltd (Crest) signed a DA in which Crest promised to apply for planning permission for and to construct commercial and residential buildings on a pre-selected site (the 'Waverley DA). ${ }^{147}$ Waverley promised to transfer land it owned on the development site to Crest, and the parties agreed to work together to acquire the other landholdings that they required. ${ }^{148}$ Waverley could then only compel Crest to commence construction following discharge of a viability condition that required a positive DVA produced after all other pre-conditions in the DA had been discharged. ${ }^{149}$

Waverley and Crest failed to acquire the privately held landholdings on the development site by agreement, so Waverley sought confirmation, in 2012, for a CPO that would complete these land acquisitions. ${ }^{150}$ The SSCLG confirmed that CPO in August 2013. ${ }^{151}$ At the time of the public inquiry, the DA obliged Crest to pay a one-off lump sum to Waverley of no less than $£ 8.76$ million for the site. ${ }^{152}$ Before the inquiry, Crest had produced a DVA that indicated that the development proposition, including this preagreed minimum price, was viable. ${ }^{153}$ At this point in the land assembly process, however, other pre-conditions in the DA had not been discharged, so the pre-inquiry DVA did not discharge the viability condition. ${ }^{154}$

In May 2016, Crest then submitted a report to Waverley's Estates Department indicating that it would only discharge the viability condition if Waverley amended the minimum price in the DA to $f^{3.19}$ million. ${ }^{155}$ Waverley's consultants advised that this amendment would still enable the Council to obtain best consideration for the transfer of the land. ${ }^{156}$ Waverley approved the necessary amendments but did so without conducting a tendering exercise. The claimants in Wylde thus argued that this breached Waverley's public procurement law duties, so Dove J's judgment considers if the claimants should have permission for judicial review of this allegation. Dove J concluded that the claimants did not have sufficient standing because they had suffered no direct disadvantage as a result of Waverley's decision to vary the minimum price. ${ }^{157}$ As with the earlier discussion regarding the Gottlieb decision, however, the point in this paper is not to examine the procurement law basis for Dove J's judgment. Rather, the point is to emphasise that Crest produced two DVAs in a relatively short period of time, either side of a CPO inquiry, which carried around markedly different outputs. These manoeuvrings indicate that there may be circumstances in which local authorities undersell land despite satisfying the legal definition of 'best consideration'. The Waverley development specifically shows that

147 Waverley and Crest have since agreed various amendments to the 2003 DA. A copy of the latest amendment is available, as of 15 October 2019, from

<https://www.waverley.gov.uk/downloads/download/544/brightwells_development_agreement $>$. The 2010 iteration of the DA was operative at the time of the CPO inquiry and the judicial review proceedings discussed above. The author has a copy available for review on request.

148 The Waverley DA, clause 3.3.

149 Ibid clause 3.6.

150 Discussed in C J Ball (2013) CPO Report to the Secretary of State for Communities and Local Government [NPCU/CPO/R3560/70501].

151 Wylde (n 11) [6].

152 Ibid [5].

153 Ball (n 150) paragraph 183.

154 Waverley BC, Brightwells Regeneration Scheme. Report to Executive (24 May 2016) paragraphs 57-61.

155 Ibid paragraph 61. See also Wylde (n 11) [7].

156 Waverley BC, Brightwells Regeneration Scheme. Report to Executive (24 May 2016) paragraph 17.

157 Cited in Wylde (n 11) at [43]-[44], cross-referencing R (on the application of Chandler) $v$ Secretary of State for Children, School and Families [2009] EWCA Civ 1011 per Arden LJ at [77]. 
some local authorities might accept significant reductions in the price that they receive for land if doing so serves the perceived public interest in facilitating property development and reordering private property rights in favour of property developers. The Winchester Development, on the other hand, shows that public pressure can lead developers to offer more money for the transfer of land and that some developers will seek to develop sites even if DVAs indicate that they will not achieve the 'required' profit margin.

The opacity of financial viability modelling and adjustable underlying inputs complicate these issues. As noted earlier, local authority planning practice suggests that some planning departments have started to adopt a more critical attitude to the use of DVAs. A recent CPO inquiry for a property development project in Seven Sisters, North London, indicates that some estates departments are also changing their practices. ${ }^{158}$ The London Borough of Haringey submitted its consultant's review of the developer's DVA to that inquiry, ${ }^{159}$ which suggests that Haringey embraced greater transparency than Winchester Council. However, the report presented at the Seven Sisters Inquiry reveals only the methodology deployed and the estimated profit. In that respect, the information disclosed is generic and broadly comparable to that which Winchester Council published during the Winchester Development.

Financial viability modelling creates mistrust, which is heightened when DAs between local authorities and property developers embed a guaranteed profit as a non-negotiable entitlement. Moreover, this paper shows that the focus on private profit can be detrimental to the provision of public goods and to public revenue-raising. On its own, this latter finding is unsurprising because conventional property development theory suggests that local authorities should not seek to generate revenue directly from a property development project but should simply promote projects that enhance the 'investability' of an area and that produce economic benefits that 'trickle down' to the locality. However, there are numerous examples of projects in which an estates department has obtained confirmation for a CPO only for its development partner to cite viability concerns to delay the commencement of construction and to extract concessions from the local authority. ${ }^{160}$ It seems essential, therefore, that local authority estates officers either establish and apply robust mechanisms enabling intensive public scrutiny of a developer's viability assumptions or pursue property development approaches that place less emphasis on a 'required' private profit.

\section{Conclusion}

Financial viability modelling presents challenges to the local authority planning officers, estates officers and councillors who engage with modelling techniques, the underlying assumptions used in modelling practices and the outputs that viability appraisals produce. This paper has examined judicial decisions and academic commentary that highlight problems arising from contestable viability inputs and that question the use of DVAs as a tool for determining such things as the quantity of affordable housing to be constructed on a site. Judicial decisions in this context focus on disputes between local authority planning departments and property developers, but this paper demonstrates that questions are also likely to arise about viability modelling practices when a local authority accepts the substance of a developer's viability outputs. Analysis of the Winchester

158 The project in question is for the regeneration of the Wards Corner site. The development company delivering the project is a subsidiary of Grainger plc, a predominantly residential property developer.

159 The author has a copy available for review on request.

160 In addition to the projects mentioned in this paper, notable examples include the Sevenstone, Westfield, Silk Street and Brent Cross projects in Sheffield, Bradford, Macclesfield and North London, respectively. 
Development, for example, illustrates how a property developer might begin planning negotiations with a local authority by making a relatively generous affordable housing offer before presenting DVAs to reduce that offer over the course of a long-term land assembly and property development project. Further discussion of the Winchester Development in the context of access to information law and judicial decisions related to the publication of viability data illustrates the paucity of community involvement in viability-related discussions. Viewing this through McAuslan's framework for examining land use planning law shows that public participation rights rarely enable members of the public to influence these discussions because access to information law often does little more than entitle outsiders to review documents after a viability-based decision has been made. In the context of local authority estates practice, examination of the Winchester Development and the project discussed in the Wylde judicial review reveals that some property developers produce DVAs showing markedly different outputs either side of public inquiries convened to confirm the use of compulsory purchase powers purportedly for public interest purposes. These two projects also show how the use of DVAs can raise questions about the price at which local authorities are willing to transfer land to property developers and the way that viability outputs affect local authority compliance with public law duties. Taken together, the findings discussed in this paper show that current viability modelling practices should only form a basis for decisionmaking in local authority planning and estates departments if they are subjected to intensive public scrutiny at the time that viability-based decisions are made. 
